\title{
摩擦重ね接合によるアルミニウム合金と炭素繊維強化樹脂の 異材接合特性に及ぼすシランカップリング処理の影響*
}

\author{
永塚 公涁**，田中 宏宜***，肖 伯律**，土谷 敦岐****，中田 一博**
}

Effect of silane coupling treatment on the joint characteristics of friction lap joined $\mathrm{Al}$ alloy / CFRP *

\author{
by NAGATSUKA Kimiaki**, TANAKA Hironobu ${ }^{* * *}$, XIAO Bolyu ${ }^{* *}$, TSUCHIYA Atsuki**** and NAKATA Kazuhiro**
}

\begin{abstract}
Dissimilar materials joining of an A5052 plate and a carbon fiber reinforced thermoplastic (CFRTP), which consisted of polyamide 6 (PA6) with $20 \mathrm{wt} \%$ carbon fiber addition, was performed using friction lap joining (FLJ) with the Al alloy plate as a top and the CFRTP plate as a bottom. The joint characteristics were evaluated to investigate effects of the surface treatment by the silane coupling treatment for A5052 and the joining speed on the joining properties. The joint strength was increased by inducing the silane coupling treatment for the A5052 plate surface. The tensile shear fracture load of the silane coupling treated FLJ joint increased with increasing the joining speed up to $6.67 \mathrm{~mm} / \mathrm{s}$, and then decreased. The maximum tensile shear fracture load of $5.0 \mathrm{kN}$ was obtained at the joining speed of $6.67 \mathrm{~mm} / \mathrm{s}$, and the fracture occurred at the CFRTP base plate with the joint efficiency of $97 \%$. The shear strength of the joint interface of the joint formed at the joining speed of $1.67 \mathrm{~mm} / \mathrm{s}$, which fractured at the joining interface by the tensile shear test, was estimated about 19MPa. The covalent bondings between the A5052 plate and the silane coupling layer, and the silane coupling layer and the CFRTP plate were indicated by inducing the silane coupling treatment.
\end{abstract}

Key Words: Friction lap joining, Al alloy, carbon fiber reinforced thermoplastic, silane coupling treatment, dissimilar materials joining

\section{1. 緒言}

近年，自動車，航空機等の輸送機器の軽量化による省エ ネルギー化㧍よび $\mathrm{CO}_{2}$ 排出量抑制への要求が高まっている. 軽量化を図る手段として, 高強度の高張力鋼薄板や軽量金 属材料であるアルミニウム（Al）合金が適用されるととも に, さらに, より軽量な樹脂材料の使用が急速に増加して いる. その中でも, 樹脂中に炭素瀻維（CF: Carbon fiber）を 配合することで, 樹脂の軽量性と, CF の高強度, 高弾性の 特徵を併せ持つ複合材料である炭素瀻維強化樹脂 (CFRP: Carbon fiber reinforced plastic)が, 特に注目されてきている ${ }^{1-3)}$. CFRP の中でも， CF と熱可塑性樹脂材料の複合材料である 炭素繊維強化熱可塑性樹脂 (CFRTP: Carbon fiber reinforced thermoplastic）は，従来の熱硬化性樹脂をマトリックスとす るCFRP と比較して, ホットプレスや射出成形による大量 生産が可能で，成形時間の短縮，製造コストの削減が実現 でき，一般自動車の構造材料として使用拡大が見达まれて

\footnotetext{
*受付日 平成27年 9 月 16 日 受理日 平成27年 9 月 30 日 平 成26年度および平成27年度秋季全国大会で発表

**正員 大阪大学 接合科学研究所 Member, Joining and Welding Research Institute, Osaka University 大阪大学 接合科学研究所 (現在三菱重工株式会社) Joining and Welding Research Institute, Osaka University (Mitsubishi Heavy Industries, Ltd.) 東レ株式会社 Toray Industries, Inc.
}

いる ${ }^{2)}$.このように金属材料のみならず樹脂材料も適材適所 で使用するマルチマテリアル化構造体の実現のためには, 金 属材料と樹脂材料の異材接合は不可欠であり，その接合技 術開発への要求が高まっている.

樹脂・CFRP と金属との異材接合方法としては，接着剂 による接着，あるいはボルト，リベットなどによる機械的 締結が一般的である ${ }^{4-7)}$. しかし，接着剂を用いる接合で は, 接合に長時間を要することや, 有機溶剤の蒸発が作業 者の健康を害するためVOC 規制（揮発性有機化合物排出規 制）対象であることなどの問題が挙げられる．機械的接合 では，前加工工程や締結金具が必要となること，設計が制 限されること, 気密性打よび水密性に劣ることなどの久点 がある，そのため短時間で強固に接合でき，かつ密着性に 優れた接合部を得ることができる新たな接合方法が必要と されている. その手段として熱可塑性樹脂を加熱，溶融さ せて金属と接合する融着法が挙げられる，金属と CFRTP の 融着法としては，レーザ溶着 ${ }^{6-12)}$, 誘導加熱接合 ${ }^{13)}$ ，超音波 接合 ${ }^{14-16)}$, 摩擦攪拌スポット溶接 ${ }^{17,18}$, 㧍よび摩擦重㸚接合

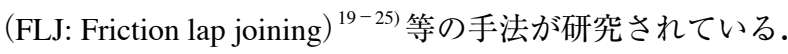

このうち，FLJは著者らが提案した新しい接合法であり， 金属と CFRTP を重ね継手とし，ッールと呼ばれる工具を高 速回転させながら金属側に押し付けることで，ッールと金 属の間に生じる摩擦によって熱可塑性樹脂を溶融させて接 合を行う方法である ${ }^{19-25)}$. FLJ では，摩擦による加熱とッー ルによる接合界面の加圧を同時に行うことができるため, 密 
Table 1 Chemical composition of A5052 (mass\%).

\begin{tabular}{cccccccccc}
\hline & $\mathrm{Si}$ & $\mathrm{Fe}$ & $\mathrm{Cu}$ & $\mathrm{Mg}$ & $\mathrm{Mn}$ & $\mathrm{Zn}$ & $\mathrm{Cr}$ & $\mathrm{Ti}$ & $\mathrm{Al}$ \\
\hline $\mathrm{A} 5052$ & 0.09 & 0.26 & 0.02 & 2.43 & 0.04 & 0.00 & 0.18 & 0.02 & Bal. \\
\hline
\end{tabular}

着性に優れた連続的な接合部を形成することが可能である.

このような金属 /CFRTP の異材接合は材料表面同士の相 互作用によって達成され，接合前の表面処理は接合強度の 向上に有効である。これまでに検討された表面処理法とし て, 表面に凹凸を形成しアンカー効果を利用して強度を上 昇させる機械的表面処理法 ${ }^{12}$, $\mathrm{Al}$ 合金に対するアルマイト 処理および研磨処理 ${ }^{20,24)}$, 樹脂に対するコロナ放電処理 ${ }^{25)}$ 等の化学的表面処理法について報告が行われている。これ らの中でも, 表面の化学状態を変化させる手法を用いて FLJを行うことで，CFRTP が母材破断を呈する程の継手が 得られることを報告した ${ }^{24)}$.

本研究では $\mathrm{Al}$ 合金/CFRTP の FLJ 接合継手強度のさら なる向上を図る目的で，接合前の $\mathrm{Al}$ 合金表面に対するシラ ンカップリング処理を行い，これが接合強度に及ぼす影響 を FLJ プロセスパラメータである接合速度を変化させて検 討し，その接合機構について考察を行った.

\section{2. 実 験 方 法}

供試材料として用いた $\mathrm{Al}$ 合金 $\mathrm{A} 5052$ は $\mathrm{Al}-\mathrm{Mg}$ 合金であ り，その板寸法は $150 \mathrm{~mm} \times 75 \mathrm{~mm} \times 2 \mathrm{~mm}$ である．その化 学組成を Table 1 に示す. CFRTP には, ポリアミド 6(PA6) を マトリックス樹脂とし， $20 \mathrm{wt} \%$ の CF が添加された，板寸 法は $150 \mathrm{~mm} \times 75 \mathrm{~mm} \times 3 \mathrm{~mm}$ の長手方向に射出成形された ものを用いた．PA6 の化学構造式は $\left(\left[\mathrm{NH}\left(\mathrm{CH}_{2}\right)_{5} \mathrm{CO}\right]_{\mathrm{n}}\right)$ であ り，極性官能基であるアミド基（CONH）を有する。なお， 使用したCFRTP には強度に異方性があり，長手方向が約 $134 \mathrm{MPa}$ ，短手方向が約 $114 \mathrm{MPa}$ である. FLJ に先立ち， CFRTP はエメリー紙\#2000にて大気中で研磨し，エタノー ルを用いて脱脂した．A5052 はエメリー紙\#800にて流水中 で湿式研磨を行った後にアセトンを用いて脱脂し，シラン カップリング処理を施した.

シランカップリング処理には，Fig. 1 に分子構造を示す アミノエチルアミノプロピルトリメトキシシラン $\left(\mathrm{C}_{3} \mathrm{H}_{6} \mathrm{NHC}_{2} \mathrm{H}_{4} \mathrm{NH}_{2} \mathrm{Si}\left(\mathrm{OCH}_{3}\right)_{3}\right)$ を主成分とする OFS-6020 Silane を純水で $0.5 \mathrm{vol} . \%$ に希釈した水溶液を用いた。アミ ノエチルアミノプロピルトリメトキシシランは, 反応性官 能基であるアミノエチルアミノプロピル基 $\left(-\mathrm{C}_{3} \mathrm{H}_{6}\right.$ $\mathrm{NHC}_{2} \mathrm{H}_{4} \mathrm{NH}_{2}$ ）にアミノ基が 2 つ存在している。 また，加水 分解基であるメトキシ基 $\left(-\mathrm{OCH}_{3}\right)$ は3 3 存在しており, 水溶液中ではメトキシシラン $\left(-\mathrm{Si}^{-} \mathrm{OCH}_{3}\right)$ は加水分解反応 によりシラノール (-Si-OH) とアルコール $\left(\mathrm{CH}_{3} \mathrm{OH}\right)$ にな $3^{26,}{ }^{27)}$. シランカップリング水溶液中に湿式研磨後の A5052 をディッピングし, 十分に乾燥させて接合に供した。

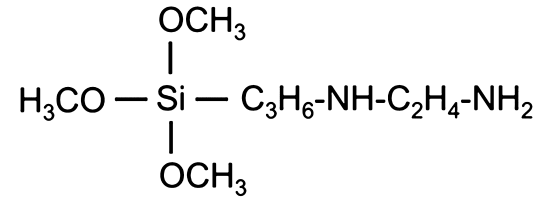

Fig. 1 Structural formula of 3-(2-Aminoethylamino) propyltrimethoxysilane.

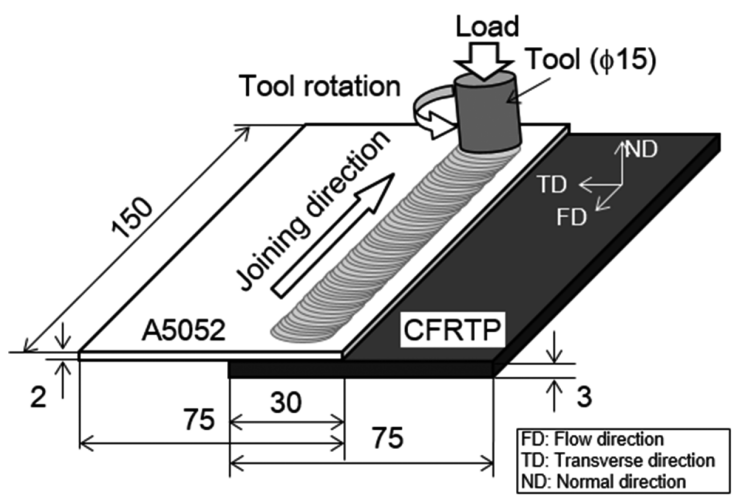

Fig. 2 Schematic illustration of the friction lap joining process. (All dimensions in $\mathrm{mm}$.)

また，比較のために A5052 の湿式研磨処理材を併せて接合 に用いた．接合に先立ち，シランカップリング処理による 表面状態の変化を検討するため, 湿式研磨後およびシラン カップリング処理後の A5052 板表面の X 線光電子分光 （XPS: X-ray photoelectron spectroscopy）分析を行った.

FLJ は，位置制御式の摩擦攪拌接合（FSW: Friction stir welding) 装置を用いて行った. Fig. 2 に FLJ の模式図を示す. 上板を A5052，下板を CFRTP とした重ね代 $30 \mathrm{~mm}$ の重ね 継手とし，表面処理を施した板面同士が向き合うように重 ねて配置して，テーブル部の裏当金の上にジグにより固定 した。その後，ッールを回転させながら A5052 板表面に押 しつけ，板表面から一定の深さまでッール先端を押し込ん だ後，ツールを一定速度で移動させて接合を行った。なお， CFRTP 板は長手方向が接合方向に一致するように配置し た。ッールは工具鋼 SKD 製であり，ショルダ径が $15 \mathrm{~mm}$, プローブなしの円柱状ッールを用いた。これは，事前に実 施した予備検討で，プローブを有するッールを用いた場合， プローブ通過部，すなわち FSW における攪拌部（SZ）に 溝状欠陥が形成され，継手強度が著しく低かったためであ る. 接合条件は, Table 2 に示す通り,ッールの押し込み深さ $0.9 \mathrm{~mm}$, 前進角 $3^{\circ}$ および回転速度 $33.3 \mathrm{~s}^{-1}$ 一定とし，接合速 度を 1.67 から $26.7 \mathrm{~mm} / \mathrm{s}$ まで変化させて接合を行った。ま た，FLJ 中の接合界面近傍の温度変化は，A5052/CFRTP 界 面の継手接合方向中央のツール通過部中心に，あらかじめ 
Table 2 Conditions of friction lap joining for A5052 and CFRTP.

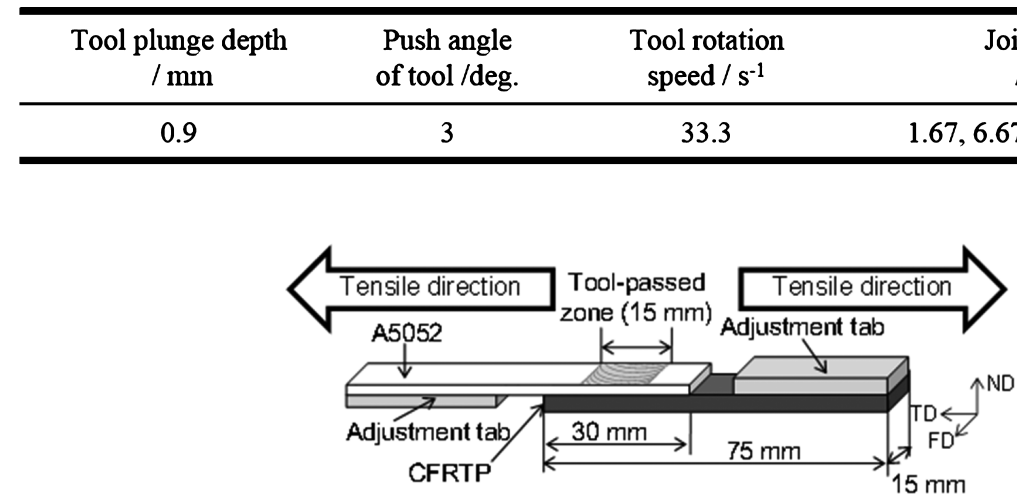

Fig. 3 Schematic illustration of tensile shear testing method.

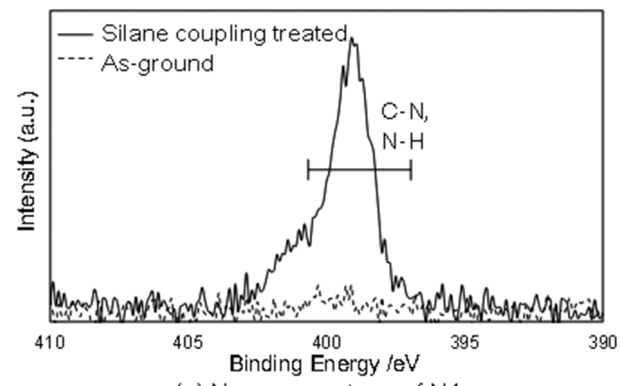

(a) Narrow spectrum of $\mathrm{N} 1 \mathrm{~s}$

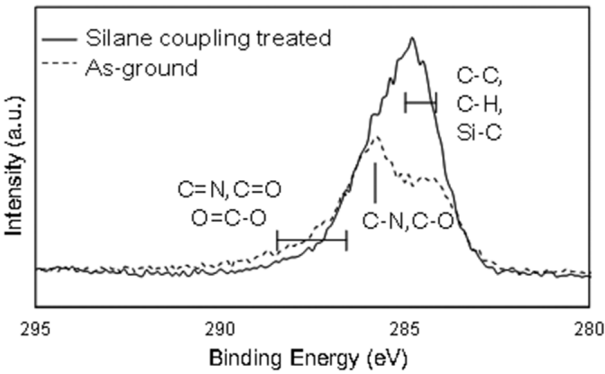

(c) Narrow spectrum of $\mathrm{C} 1 \mathrm{~s}$

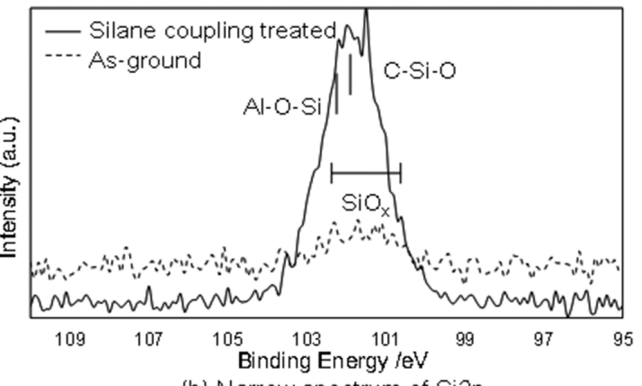

(b) Narrow spectrum of Si2p

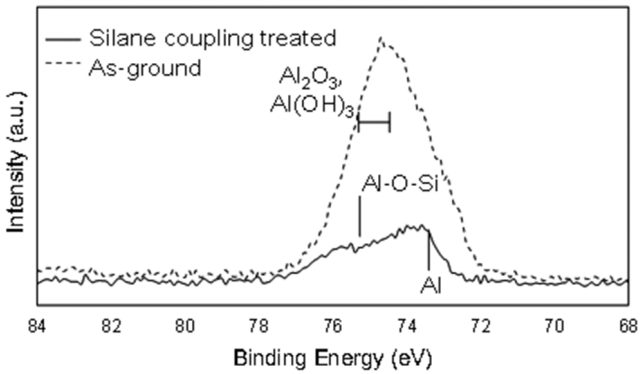

(d) Narrow spectrum of Al2p

Fig. 4 XPS narrow spectrums of (a) N1s, (b) Si2p, (c) C1s and (d) A12p of as-ground and silane coupling treated surface of A5052.

線径 $0.2 \mathrm{~mm}$ のガラス被覆 $\mathrm{K}$ 型熱電対を挿入して実測した.

FLJ 後の接合継手は，外観観察後，接合方向と垂直に， 幅約 $5 \mathrm{~mm}$ の短冊状試験片形状に切り出し, 二液混合型の エポキシ樹脂に埋め込み，エメリー紙粗研磨およびダイヤ モンドペーストによるバフ研磨の後, 光学顕微鏡（OM: Optical microscope）および走査型電子顕微鏡（SEM： Scanning electron microscope) を用いて断面の組織観察を行っ た。さらに，集束イオンビーム（FIB: Focused ion beam）加工 により厚さ約 $100 \mathrm{~nm}$ の薄状試験片を作成し，透過型電子顕 微鏡（TEM: Transmission electron microscope）およびエネル ギー分散型 X 線分析器 (EDS: Energy dispersive spectrometry) を用いて接合継手界面の微細構造解析を行った。

次に, Fig. 3 に示す引張せん断試験により接合継手強度を 評価した。引張せん断試験片は, 継手を接合方向と垂直に 幅 $15 \mathrm{~mm}$ の短冊状に切り出した試験片である．試験に際し ては，曲げモーメントの発生を防ぐため試験片にスペーサ
一を固定して，継手の接合方向と垂直に荷重を加え，破断 に至るまでの最大荷重を測定した。なお，継手の引張方向 は CFRTP 板の短手方向に一致する．引張せん断試験は，ク ロスヘッドスピード $8.3 \times 10^{-3} \mathrm{~mm} / \mathrm{s}$ にて，それぞれの接合条 件で接合した継手に対して，3 回ずつ試験を行った。引張 せん断試験後の試験片の破面観察を OM および SEM-EDS により行った。

\section{3. 実験結果および考察}

\section{1 シランカップリング処理による A5052 表面の化学状 態変化}

湿式研磨処理およびシランカップリング処理を施した A5052のXPS による表面の化学状態分析結果を Fig. 4 (a)(d) に示す. それぞれ N1s, Si2p，C1s および A12p のナロース ペクトルである。まず，湿式研磨処理面においては，主と 
して酸化物 $\left(\mathrm{Al}_{2} \mathrm{O}_{3}\right)$ および水酸化物 $\left(\mathrm{Al}(\mathrm{OH})_{3}\right)$ 状態の $\mathrm{Al}$ が検出された. シランカップリング処理面においては，Si およびNの存在が認められ，それぞれ C-Si-O および $\mathrm{Si}-\mathrm{O}_{\mathrm{x}}$ 結合，C-N および N-H 結合等の結合状態であった。これら はシランカップリング水溶液中で形成されたシラノール（$\mathrm{Si}-\mathrm{OH}$ ）および反応性官能基であるアミノエチルアミノプロ ピル基 $\left(-\mathrm{C}_{3} \mathrm{H}_{6} \mathrm{NHC}_{2} \mathrm{H}_{4} \mathrm{NH}_{2}\right)$ によるものである.さらに， $\mathrm{Si} 2 \mathrm{p}$ からは Al-O-Si 結合 ${ }^{28)}$ の存在も示唆された。また， C1s に注目すると，C-C，C-H および Si-C 結合が検出され，こ れは同様にシランカップリング剤に起因すると考えられる. シランカップリング処理後の Al2p の結合状態については, 詳細な分析が困難であるが，Si2p と同様に Al-O-Si 結合 ${ }^{28)}$ の 存在が示唆された。これは湿式研磨の際にA5052 表面に形 成された水酸化アルミニウム中のヒドロキシル基 (-OH) 等とシランカップリング水溶液中のシラノール (-Si-OH) が脱水縮合反応を生じ, -Si-O-Al として共有結合が生じた ためと推察される ${ }^{26-28)}$.

\section{2ＦLJ 中の温度履歴および接合部組織}

本研究で検討した FLJ の接合条件では，いずれの条件で も A5052 と CFRTPの接合が可能であった.ツール通過部は 滑らかな表面状態を呈し, 大きなバリは認められなかった.

Fig. 5 に接合速度 $1.67,20.0$ および $26.7 \mathrm{~mm} / \mathrm{s}$ における A5052 と CFRTP の FLJ 継手の接合界面の温度履歴を示す. 測定地点にツールが接近するにともない温度は急激に上昇 し，ツール通過後は速やかに低下した。いずれの接合速度 においても, ツール通過部中央における最高到達温度は約 $770 \mathrm{~K}$ であり, 接合速度の違いによる最高到達温度には大き な差異は認められなかった。また, 最高到達温度は, CFRTP のマトリックスであるPA6 の融点および熱分解温度 を上回っており，これらの温度以上に加熱されている時間 は接合速度の増加とともに短くなった。すなわち，接合速 度の増加とともにCFRTP の熱分解は抑制されるが，その一 方でマトリックス材である PA6 が溶融状態でA5052に密着

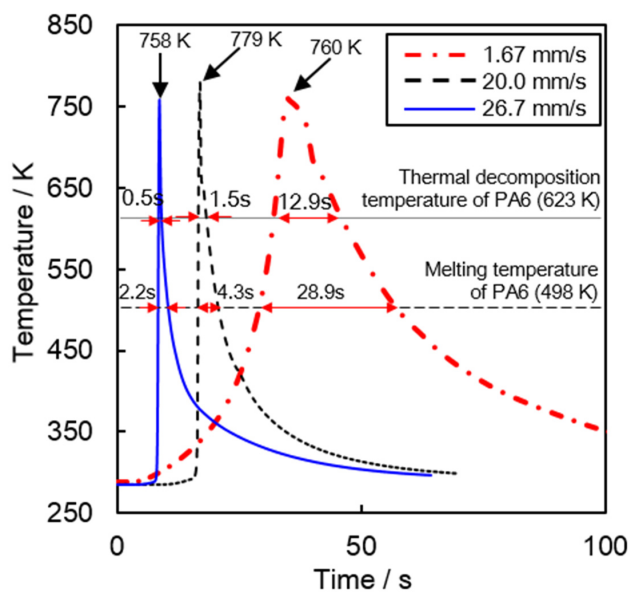

Fig. 5 Temperature profiles at the interface of A5052 and CFRTP during FLJ at the joining speed of $1.67,20.0$ and $26.7 \mathrm{~mm} / \mathrm{s}$.
する時間は短くなり，濡れ広がり面積が減少することや界 面の反応時間が短くなることで，接合面積が減少する傾向 にあったと考えられる。

接合速度 $1.67 ， 6.67$ および $26.7 \mathrm{~mm} / \mathrm{s}$ にて接合したシラン カップリング処理を施したA5052 と CFRTP との接合部断 面の OM によるマクロ組織を Fig. 6 に，また SEM によるツ ール通過部直下の界面ミクロ組織を Fig. 7 に示す.

いずれの接合速度においてもツール通過部では軟化した A5052 およびCFRTP がッールの押し付け荷重によって下凸 型に変形した．接合速度の低下にともなって，その変形量 は大きくなり，溶融した CFRTP がッール通過部の外側に押 し出される量が増加し，CFRTPの板厚も減少した．接合界 面に接している CFRTP では，CF の配向性が乱れた領域， すなわちマトリックスであるPA6の溶融域が認められ，こ の溶融域の深さは接合速度の増加にともない減少した。ま た，いずれの接合速度でも CFRTP の溶融域で滑らかな内面 を有するボイドが認められ，そのボイド数は接合速度の増 加とともに増加する傾向を示した．これらのボイドは， CFRTP のマトリックスであるPA6 中に吸水された水分の加 熱による排出，およびPA6の熱分解ガスが原因で発生した と考えられる ${ }^{29,30)}$. ボイドの生成量のみを考慮すると，接 合速度が小さい程，入熱量の増加により加熱時間が増加す るためにその生成量は増加すると考えられるが，実際の FLJ 継手断面では接合速度が大きい程，ボイド量が増加し た。これは接合速度が小さい場合は，広い領域で樹脂が溶 融しッール通過部の外側へ排出され，この時にボイドも一 緒に接合部の外側に排出されたために，接合部近傍でのボ

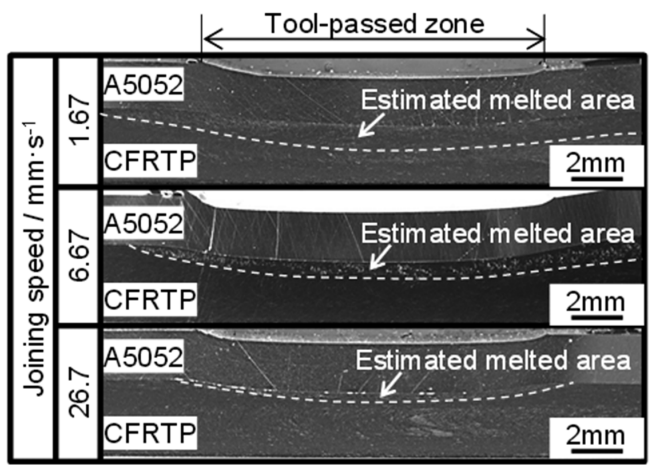

Fig. 6 Cross-sectional macrostructures of FLJ joints formed at the joining speed of $1.67,6.67$ and $26.7 \mathrm{~mm} / \mathrm{s}$.

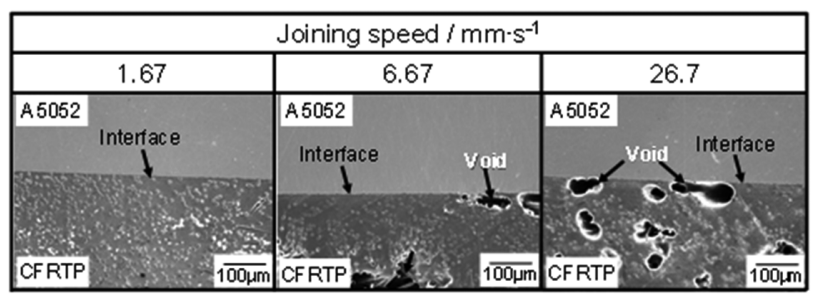

Fig. 7 Secondary electron images (SEIs) at interfaces of FLJ joints formed at the joining speed of $1.67,6.67$ and $26.7 \mathrm{~mm} / \mathrm{s}$. 


\section{イドの残留量が減少したと考えられる.}

Fig. 8 に接合速度 $20.0 \mathrm{~mm} / \mathrm{s}$ にて FLJ を行った湿式研磨処 理およびシランカップリング処理を施した A5052/CFRTP 接合界面の TEM による明視野像および EDS による元素分 析結果を示す。いずれの継手においても，接合界面では CFRTP マトリックスであるPA6 と A5052 がナノメートル オーダーにおいて密着し接合されていた. 湿式研磨処理を 施した継手では，接合界面に厚さ約 $30 \mathrm{~nm}$ の $\mathrm{Mg}$ と $\mathrm{O}$ が濃 化した界面層が認められ，制限視野電子線回折の結果， $\mathrm{MgO}$ と同定された。これらの $\mathrm{MgO}$ 層は, FLJによる加熱 によって $\mathrm{Al}$ 合金表面の $\mathrm{Al}_{2} \mathrm{O}_{3}$ 自然酸化皮膜が $\mathrm{Al}$ 合金中に 含まれる Mgによる還元作用で形成されたと考えられる ${ }^{31-33)}$. シランカップリング処理を施した継手においても，同様に

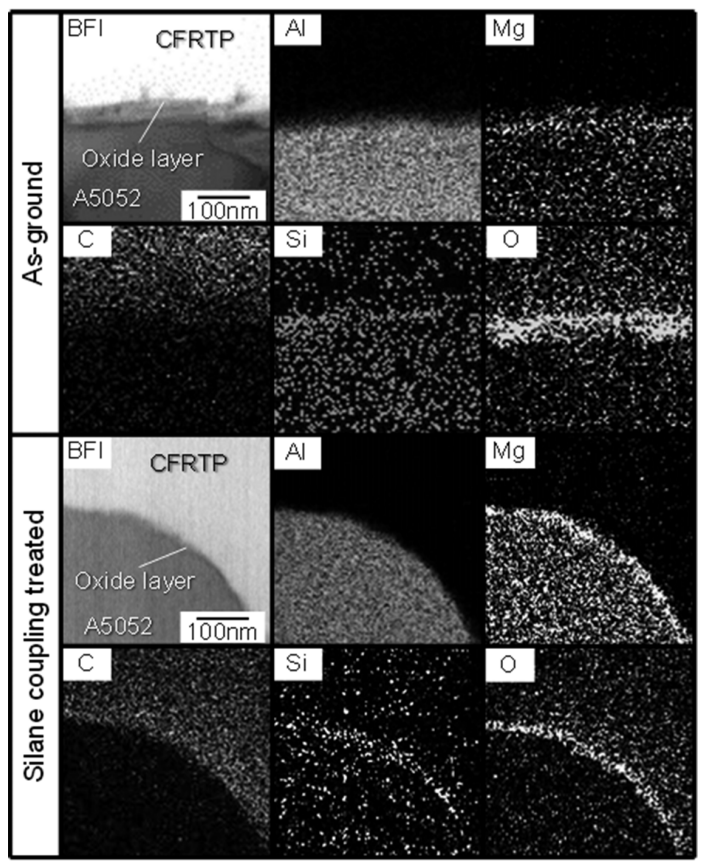

Fig. 8 TEM bright field images (BFIs) and element distributions of Al, $\mathrm{Mg}, \mathrm{C}, \mathrm{Si}$ and $\mathrm{O}$ at the interface of as-ground and silane coupling treated A5052 plates/ CFRTP FLJ joints formed at the joining speed of $20.0 \mathrm{~mm} / \mathrm{s}$.
$\mathrm{MgO}$ 層が認められた。さらにCFRTP 側にはシランカップ リング剂に起因すると考えられる厚さ数〜十数 $\mathrm{nm}$ の Si 濃 化層が認められた。すなわち，これらの材料の接合界面は， 湿式研磨処理を施した場合では A5052／MgO／PA6 CFRTP，一方，シランカップリング処理を施した場合では $\mathrm{A} 5052 / \mathrm{MgO} /$ シランカップリング層 $/ \mathrm{PA} 6 / \mathrm{CFRTP}$ から なる界面構造をとることが明らかとなった。 なお，シラン カップリング処理材では 3.1 で述べたようにFLJ 接合前にお いて A5052 表面とシランカップリング層の間には Al-O-Si 結合が認められたことから，FLJによる加熱後は前述の還 元作用で Mg-O-Si として共有結合を介してこれらは接合さ れていると考えられる。

\section{3 接合継手の引張せん断強度}

Fig. 9 に継手の引張せん断破断荷重に及ぼすシランカップ リング処理および接合速度の影響を，また Fig. 10 にシラン カップリング処理を施した A5052／CFRTP 継手の引張せん 断試験後の試験片のマッチング破面および破断場所と接合 部との関係が明らかになる側面からの外観を示す。

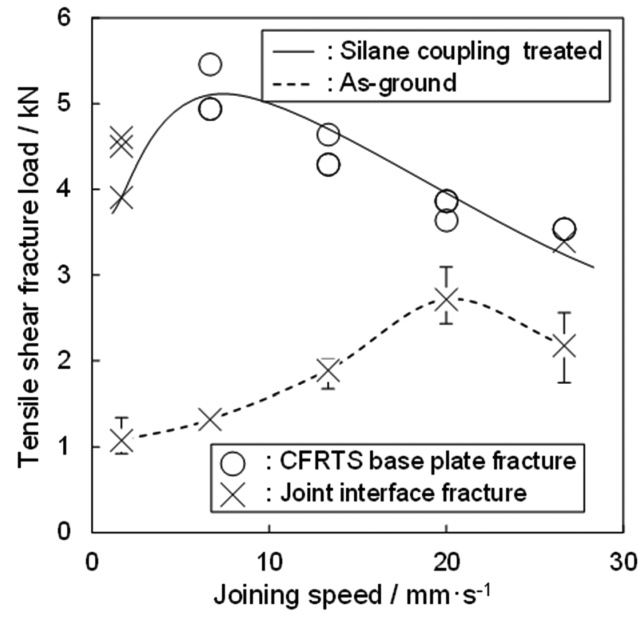

Fig. 9 Effect of the silane coupling treatment and the joining speed on the tensile shear fracture load of FLJ joint.

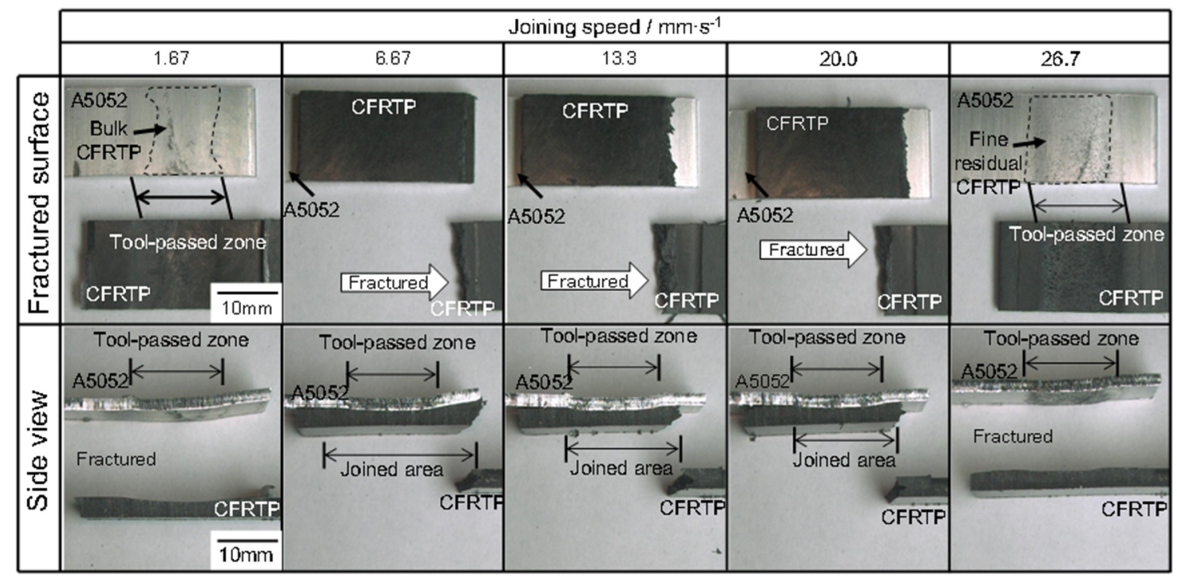

Fig. 10 Fractured surfaces and side views of FLJ joints formed at various joining speeds after tensile shear test. 
引張せん断破断荷重は, シランカップリング処理を施す ことで, いずれの接合速度においても湿式研磨処理材と比 較すると著しく増加した。これはシランカップリング処理 によってA5052／CFRTP の接合界面が強固に接合されたこ とを意味している。

次に, 接合速度と引張せん断破断荷重の関係に注目する と, いずれの表面処理の継手においても接合速度の増加と ともに破断強度は増加し最大值を示した後, それ以上では 接合速度の増加にともない低下した. 最大值は, シランカ ップリング処理を施した場合は接合速度 $6.67 \mathrm{~mm} / \mathrm{s}$ で約 $5.0 \mathrm{kN}$ であり, 湿式研磨処理を施した場合は接合速度 $20.0 \mathrm{~mm} / \mathrm{s}$ で約 $2.7 \mathrm{kN}$ であった.

これらの継手の破断位置は, 湿式研磨処理を施した継手 では，いずれの接合速度においてもA5052/CFRTP の接合 界面であった。一方, シランカップリング処理を施した継 手においては，接合速度 1.67 および一部 $26.7 \mathrm{~mm} / \mathrm{s}$ では, 同様に接合界面破断を呈する継手が認められたが，接合速 度 6.67 から $20.0 \mathrm{~mm} / \mathrm{s}$ では, いずれも CFRTP 板の母材部で 破断が生じた。また，これらの界面破断を呈した継手にお いても A5052 側破面のツール通過部には, CFRTP 部で破断 したと考えらえる付着物が認められたことより, 巨視的に は接合界面破断ではあるものの, 一部で CFRTP 部が剥離破 断していると考えられる.

次に, CFRTP 板の母材部で破断した継手について, 破断 荷重をCFRTP の板厚 $(3 \mathrm{~mm})$ と引張せん断試験片幅 $(15 \mathrm{~mm})$ で除して引張強度とし, これと CFRTP の受入材 の短手方向の引張強度 $(114 \mathrm{MPa})$ との割合として継手効率 を算出した。なお, 継手の引張せん断試験方向は, 前述の 通り CFRTP の短手方向に一致する。 その結果, 継手効率は 接合速度 $6.67 \mathrm{~mm} / \mathrm{s}$ で約 $97 \%, 13.3 \mathrm{~mm} / \mathrm{s}$ で約 $81 \%$ および $20.0 \mathrm{~mm} / \mathrm{s}$ で約 $74 \%$ であった。ささに，これらの CFRTP 板 母材破断が生じた継手の破断位置は, 接合速度 13.3 および $20.0 \mathrm{~mm} / \mathrm{s}$ ではツール通過部の端部であり, 接合速度
$6.67 \mathrm{~mm} / \mathrm{s}$ ではツール通過部の端部から約 $7.5 \mathrm{~mm}$ 離れた重 ね代の端部であった。接合速度 13.3 および $20.0 \mathrm{~mm} / \mathrm{s}$ にお いては，引張せん断試験に際して，ツール通過部の外側の 重ね代に相当する部分で，まず接合界面の剥離が容易に生 じ，その後，ツール通過部は強固に接合されていたため， ツール通過部端部において CFRTP 板の母材破断が生じた. 一方，より低速度の $6.67 \mathrm{~mm} / \mathrm{s}$ では，接合速度の低下にとも なって入熱量が増加し，このため接合部幅が広くなりツー ル通過部の外側も含めた幅 $30 \mathrm{~mm}$ の重ね代全域が強固に接 合された結果，重ね代の端部で破断が生じたと考えられる. なお, ツール通過部の外側の重ね代部分が先行して剥離す る現象は接合界面破断を呈した継手においても同様に認め られた。

このようにCFRTP 板の母材破断を呈したにもかかわら ず，継手効率が $100 \%$ とならずに接合速度によって変化し， 特に接合速度の増加にともなって低下した理由として，次 のことが考えられる．重ね継手の引張せん断試験では接合 部には引張軸力に加えて, 曲げモーメントが発生し, 接合 部の幅が小さいほど曲げモーメントが大きく作用するため に引張せん断強度が低下することが知られている ${ }^{34)}$.引張 せん断試験中の CFRTP 部の曲げ変形をその場観察した結 果, 重ね代の端部で CFRTP 板が母材破断した接合速度 $6.67 \mathrm{~mm} / \mathrm{s}$ の場合，すなわち，接合部幅が広い場合に比べ て，ツール通過部のみが強固に接合され，それ以外の重ね 代部分では試験中に容易に剥離した接合速度 13.3 おび $20.0 \mathrm{~mm} / \mathrm{s}$ の場合，すなわち，接合部幅が狭い場合では，明 らかに試験中の曲がり角度が増加した。このため, CFRTP 板母材で破断を呈した継手においては，接合速度の増加と ともに継手効率が低下したと考えられる.

次に界面破断を呈した継手の破面を比較する目的で，Fig． 11 にシランカップリング処理材の接合速度 $1.67 \mathrm{~mm} / \mathrm{s}$ およ び $26.7 \mathrm{~mm} / \mathrm{s}$ ，ならびに湿式研磨処理材の接合速度 $26.7 \mathrm{~mm} / \mathrm{s}$ の継手のツール通過部のそれぞれ A5052 側破面の代表的な

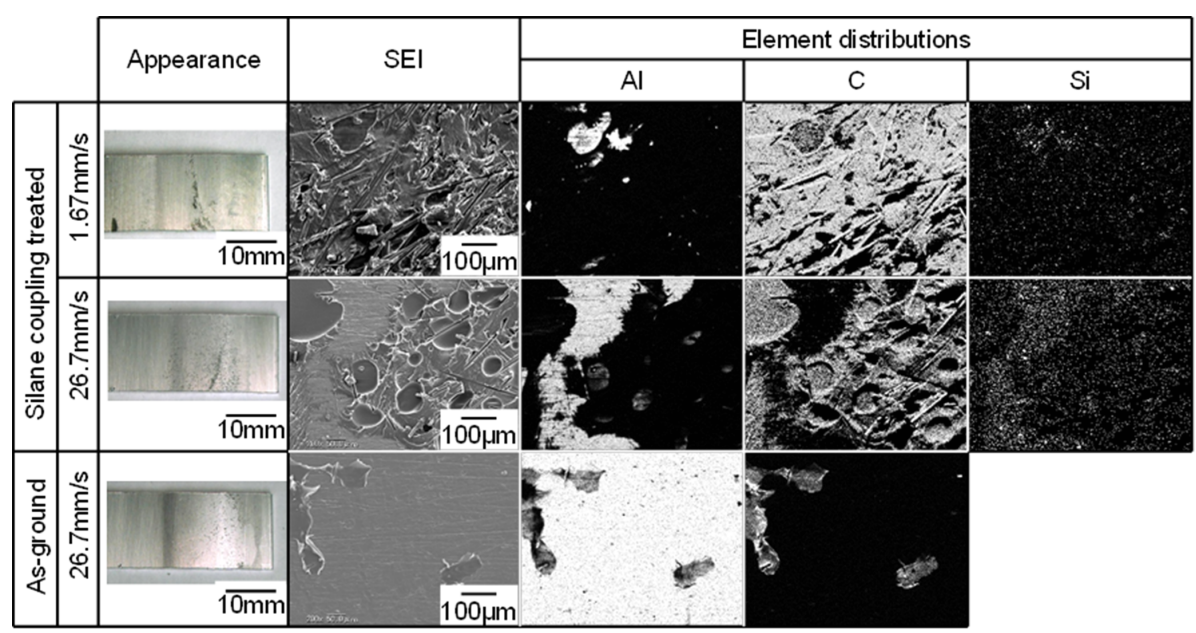

Fig. 11 OM images, SEIs and element distributions of $\mathrm{Al}, \mathrm{C}$ and $\mathrm{Si}$ on fractured surfaces of FLJ joints which fractured at the joint interface by tensile shear test. 
ミクロ組織を示す. シランカップリング処理に関わらず, いずれの継手からもA5052 側破面のツール通過部には CFRTPに起因すると考えられる付着物が認められた. 湿式 研磨処理材の継手では，ごく一部で, CFRTPのマトリック ス樹脂の溶融部に発生したボイドに起因すると考えられる, 表面が滑らかな付着物が認められた。 これに対し, シラン カップリング処理を施した接合速度 $26.7 \mathrm{~mm} / \mathrm{s}$ の継手では, ボイド部と考えられる付着物の量および面積割合が著しく 増加した. また, 付着物が認められない領域からはシラン カップリング剂に起因すると考えられる Si が検出された. これらの結果より, 接合速度が $26.7 \mathrm{~mm} / \mathrm{s}$ と高速度の接合条 件では接合界面近傍の CFRTP 内で発生したボイド部分で破 断が生じるとともに，入熱量が不十分なためにシランカッ プリング層と CFRTP マトリックスであるPA6の反応が十 分に生じず，このため接合強度が低下したと考えられる. これに対し，シランカップリング処理材で接合速度が $1.67 \mathrm{~mm} / \mathrm{s}$ と遅い継手の A5052 側破面では, 多くの領域にお いてマトリックス材であるPA6に加えて, CF を伴った塊 状の付着物が認められた。 これは接合界面が強固に接合さ れていたにも関わらず，高温での加熱時間が増加したため にPA6が劣化し, CFRTP の一部が母材剥離する形で接合界 面に沿って破断したためと考えられる ${ }^{24,29,30)}$.

このような付着物はツール通過部において多数認められ， ツールによる加圧力が作用しているツール通過部が特に強 固に接合されていると考えられる. そこで界面破断を呈し た継手について, ツール通過部に相当するッールのショル ダ径 $(15 \mathrm{~mm})$ と引張せん断試験片幅 $(15 \mathrm{~mm})$ の積をみか け上の接合面積 $\left(225 \mathrm{~mm}^{2}\right)$ として, 継手破断荷重を除した 值を継手のせん断強度として算出した。 その結果, せん断 強度は接合速度 $1.67 \mathrm{~mm} / \mathrm{s}$ では約 $19 \mathrm{MPa}$ ，および $26.7 \mathrm{~mm} / \mathrm{s}$ では約 $15 \mathrm{MPa}$ であった。なお, 接合速度 6.67 から $20.0 \mathrm{~mm} / \mathrm{s}$ の継手では, CFRTP 母材部で破断が生じたため, 接合界面の引張せん断破断荷重の測定は困難であるが，同 様にツール通過部の面積で継手の破断荷重を除した場合, せ ん断強度は $6.67 \mathrm{~mm} / \mathrm{s}$ では約 $22 \mathrm{MPa}, 13.3 \mathrm{~mm} / \mathrm{s}$ では約 $19 \mathrm{MPa}, 20.0 \mathrm{~mm} / \mathrm{s}$ では約 $17 \mathrm{MPa}$ となった。

\section{4 考察}

以上の結果より, 接合前の A5052 材表面に対しシランカ ップリング処理を施すことで, FLJにより異材接合した A5052 / CFRTP の接合強度が著しく増加することを明らか にした.このように接合強度が増加した理由について，接 合界面に働く相互作用を検討し考察を行った.

FLJ 等の融着法による金属 /CFRTP の直接接合のメカニ ズムとして, アンカー効果等の機械的接合力, ファンデル ワールスカ，および金属表面の酸化物等と CFRTP のマトリ ックス樹脂中の極性官能基の間に作用する水素結合力等が 提案されている ${ }^{12,26,35,36)}$.これまでの FLJによる $\mathrm{Al}$ 合金, 鉄鋼材料および $\mathrm{Mg}$ 合金/PA6 および PE の異材接合の研究

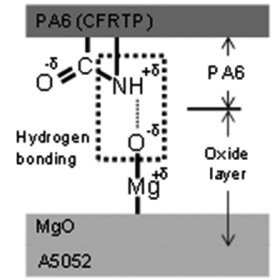

(a) As-ground

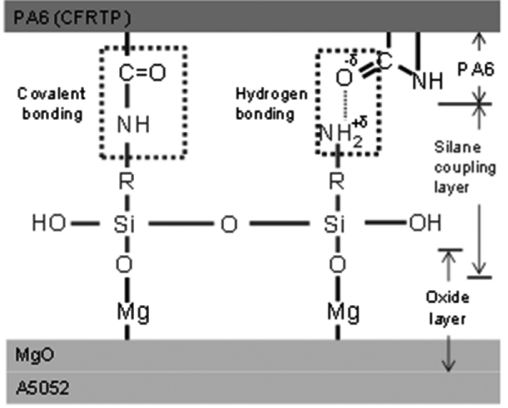

(b) Silane coupling treated
Fig. 12 Schematic illustrations of estimated bonding mechanism of (a) as-ground and (b) silane coupling treated A5052/ CFRTP.

結果 ${ }^{19-25)}$ より，これらの接合メカニズムの中でも，金属表 面に形成された酸化物を構成する電気的にマイナス性を帯 びた酸素（O）と樹脂側のプラス性を帯びた水素（H）との 間で生じる水素結合力による影響が大きいことを明らかに した. Fig. 12 には, これらの結果に基づいて，金属表面に湿 式研磨処理とシランカップリング処理を施した場合に推察 されるA5052/CFRTP 継手の接合メカニズムの模式図を比 較して示す.

CFRTP のマトリックスであるPA6には，極性官能基であ るアミド基 (-CONH-) が存在し，アミド基には電気陰性度 の高い $\mathrm{O}$ および $\mathrm{N}$ と共有結合し電気的にプラス性を帯びた $\mathrm{H}^{+\delta}$ が存在する. A5052 の湿式研磨処理材においては, その 接合界面に $\mathrm{A} 5052$ の酸化物である $\mathrm{MgO}$ が存在しており,こ の構成原子である $\mathrm{O}$ は分極により電気的にマイナス性を帯 びている.このため, 湿式研磨処理材と CFRTPは, A5052 の酸化物である $\mathrm{MgO}$ の $\mathrm{O}^{-\delta}$ と $\mathrm{PA} 6$ のアミド基中の $\mathrm{H}^{+\delta}$ との 水素結合による結合力が生じる ${ }^{22,24)}$.

これに対し，シランカップリング処理を施した場合では， Fig. 4 および Fig. 8 の XPS およびTEMによる分析で示した 通り, $\mathrm{A} 5052$ の酸化皮膜 $\mathrm{MgO}$ とシランカップリング剂のシ ラノールが反応することで, Mg-O-Si からなる共有結合を 介して A5052 表面にシランカップリング層 $\left(\mathrm{C}_{3} \mathrm{H}_{6} \mathrm{NHC}_{2} \mathrm{H}_{4} \mathrm{NH}_{2} \mathrm{Si}(\mathrm{OH})_{3}\right)$ が形成された。このシランカッ プリング層には, 極性官能基であるアミノ基 $\left(-\mathrm{NH}_{2}\right)$ が存 在しているため, CFRTP マトリックスのPA6 との間には, 湿式研磨処理材と同様に水素結合による結合力が生じると 考えられる.すなわち，シランカップリング層のアミノ基 には，電気陰性度の低い $\mathrm{N}$ と結合し，分極により電気的に プラス性を帯びている $\mathrm{H}^{+\delta}$ が存在し, この $\mathrm{H}^{+\delta}$ と PA6 中の アミド基中の電気的にマイナスを帯びている $\mathrm{O}^{-\delta}$ や $\mathrm{N}^{-\delta}$ との 間で水素結合による結合力が生じる ${ }^{26,27)}$.

さらに, シランカップリング処理の特徴として, シラン カップリング層中のアミノ基と PA6が共有結合であるアミ ド結合を形成していることが考えられる。すなわち, PA6 はその分子鎖の末端にカルボキシル基 (-COOH) およびア ミノ基 $\left(-\mathrm{NH}_{2}\right)$ を有することが知られている37). また, FLJ 
においては，接合界面近傍でCFRTPマトリックスである PA6の熱分解が生じていることを過去の研究より明らかに しており ${ }^{24)}$ ，長鎖状のPA6 は熱分解により分断される。こ のようなPA6 分子鎖末端のカルボキシル基，および分断さ れて生成した末端はシランカップリング層中のアミノ基と アミド結合等の共有結合を形成すると考えられる ${ }^{26,27)}$.こ のようにして, シランカップリング処理材を用いた場合で は, A5052 とシランカップリング層が共有結合，およびシ ランカップリング層と CFRTP マトリックスのPA6が水素 結合および共有結合を生じることで, A5052 と CFRTPが強 固に接合されたと考えられる.

また，共有結合による結合力は水素結合の約十倍以上 ${ }^{26)}$ と著しく大きいことが知られており, シランカップリング 処理を施すことで, 継手強度が著しく増加した理由として は, A5052 とシランカップリング層, およびシランカップ リング層と CFTTP マトリックスであるPA6の接合界面が いずれも共有結合によって接合されたためであると考えら れる.

\section{4. 結 論}

湿式研磨処理およびでシランカップリング処理を施した A5052を用いて, A5052/CFRTP (PA6+20wt\%CF) の FLJに よる異材接合を行い, シランカップリング処理および接合 速度が接合特性に及ぼす影響を検討した結果, 以下のこと が明らかになった。

1. シランカップリング処理を施すことで, A5052/CFRTP の接合強度はいずれの接合速度においても著しく増加 し, 接合速度 $6.67 \mathrm{~mm} / \mathrm{s}$ において引張せん断破断荷重は 最大值の約 $5 \mathrm{kN}$ となった. 接合速度 $6.67 \mathrm{~mm} / \mathrm{s}$ から $20.0 \mathrm{~mm} / \mathrm{s}$ においてはいずれの継手も CFRTP 板の母材の 引張破断が生じ, 継手効率は最大で約 $97 \%$ であった。 これ以上接合速度が大きい場合でも, 小さい場合でも界 面破断が生じて継手強度は低下した。 なお，界面破断を 呈した接合速度 $1.67 \mathrm{~mm} / \mathrm{s}$ における継手の接合界面のせ ん断強度は約 $19 \mathrm{MPa}$ であった。

2. シランカップリング処理を施して FLJを行うことで, $\mathrm{A} 5052$ の酸化皮膜である $\mathrm{MgO}$ とシランカップリング層, ならびにシランカップリング層と CFRTP 中のマトリッ クスであるPA6が接合された.

\section{謝辞}

本研究の一部は, 平成26年度 NEDO 委託事業（未来開 拓研究プロジェクト)「革新的新構造材料等研究開発」およ び JSPS 科研費 26820326 の助成を受けたものである.

\section{参 考 文 献}

1) J. C. Williams, and E. A. Starke Jr.: Progress in structural materials for aerospace systems, Acta Materialia, 51 (2003) 5775-5799.

2) S. Y. Fu, B. Lauke, E. Mäder, C. Y. Yue, and X. Hu: Tensile properties of short-glass-fiber- and short-carbon-fiber reinforced polypropylene composites, Composite Part A, 31 (2000) 1117-1125.

3) C. K. Narula, J. E. Allison, D. R. Bauer, and H. S. Gandhi: Materials chemistry issues related to advanced materials applications in the automotive industry, Chemistry of material, 8 (1996) 987-1003.

4) A. Finka, P. P. Camanhob, J. M. Andrésc, E. Pfeifferd, and A. Obste: Hybrid CFRP/titanium bolted joints: Performance assessment and application to a spacecraft payload adaptor, Composites Science and Technology, 70 (2010) 305-317.

5) S. B. Kumara, I. Sridhara, S. Sivashankera, S. O. Osiyemib, and A. Bagc: Tensile failure of adhesively bonded CFRP composite scarf joints, Materials Science and Engineering B, 132 (2006) 113-120.

6) K. W. Jung, Y. Kawahito, M. Takahashi, and S. Katayama: Laser direct joining of carbon fiber reinforced plastic to aluminum alloy, Journal of Laser Applications, 25, 032003 (2013) 1-6.

7) S. Katayama, and Y. Kawahito: Laser direct joining of metal and plastic, Scripta Materialia, 59 (2008) 1247-1250.

8) X. Tan, J. Zhang, J. Shan, S. Yang, and J. Ren: Characteristics and formation mechanism of porosities in CFRP during laser joining of CFRP and steel, Composite Part B, 70 (2015) 35-43.

9) M. Wahba, Y. Kawahito, and S. Katayama: Laser direct joining of AZ91D thixomolded $\mathrm{Mg}$ alloy and amorphous polyethylene terephthalate, Journal of Materials Processing Technology, 211 (2011) 1166-1174.

10) Y. Kawahito, and S. Katayama: Innovation of laser direct joining between metal and plastic, Transactions of JWRI, 39 (2010) 50-52.

11) K. W. Jung, Y. Kawahito, and S. Katayama: Laser Direct Joining of CFRP to Metal or Engineering Plastic, Transactions of JWRI, 42 (2013) 5-8.

12) M. Hino, Y. Mitooka, K. Murakami, K. Urakami, H. Nagase, and T. Kanadani: Effect of Aluminum Surface State on Laser Joining between 1050 Aluminum Sheet and Polypropylene Resin Sheet Using Insert Materials, Materials Transactions, 52 (2011) 10411047.

13) P. Mitschang, R. Velthuis, S. Emrich, and M. Kopanarski: Induction heated joining of aluminum and carbon fiber reinforced nylon 66 Journal of thermoplastic composite materials, 22 (2009) 767-801.

14) F. Balle, G. Wagner, and D. Eifler: Ultrasonic spot welding of aluminum sheet/carbon fiber reinforced polymer - joints, Materialwissenschaft und Werkstofftechnik, 38 (2007) 934-938.

15) F. Balle, G. Wagner, and D. Eifler: Ultrasonic Metal Welding of Aluminium Sheets to Carbon Fibre Reinforced Thermoplastic Composites, Advanced Engineering Materials, 11 (2009) 35-39.

16) F. Balle, and D. Eifler: Statistical test planning for ultrasonic welding of dissimilar materials using the example of aluminumcarbon fiber reinforced polymers (CFRP) joints, Materialwissenschaft und Werkstofftechnik, 43 (2012) 286-292.

17) S. T. Amancio-Filho, C. Bueno, J. F. dos Santos, N. Huber, and E. Hage Jr.: On the feasibility of friction spot joining in magnesium/fiber-reinforced polymer composite hybrid structures, Materials Science and Engineering A, 528 (2011) 3841-3848.

18) F. Yusof, Y. Miyashita, N. Seo, Y. Mutoh, and R. Moshwan: Utilising friction spot joining for dissimilar joint between aluminium alloy (A5052) and polyethylene terephthalate, Science and Technology of Welding and Joining, 17 (2012) 544-549.

19) D. Kitagawa, K. Nagatsuka, and K. Nakata: Direct joining of plastics to carbon steel by friction lap joining, Proceedings of the 1st 
International Joint Symposium on Joining and Welding (2013) 111114.

20) T. Okada, S. Uchida, and K. Nakata: Direct joining of aluminum alloy and plastic sheets by friction lap processing, Materials Science Forum, 794-796 (2014) 395-400.

21) F. C. Liu, J. Liao, and K. Nakata: Joining of metal to plastic using friction lap welding, Materials \& Design, 54 (2014) 236-244.

22) K. Nagatsuka, T. Onoda, T. Okada, and K. Nakata: Direct dissimilar joining of aluminum alloys and polyamide 6 by friction lap joining, Quarterly Journal of The Japan Welding Society, 32 (2014) 235241. (in Japanese)

23) F. C. Liu, K. Nakata, J. Liao, S. Hirota, and H. Fukui: Reducing bubbles in friction lap welded joint of magnesium alloy and polyamide, Science and Technology of Welding and Joining, 19 (2014) 578-587.

24) K. Nagatsuka, S. Yoshida, A. Tsuchiya, and K. Nakata: Direct joining of carbon-fiber-reinforced plastic to an aluminum alloy using friction lap joining, Composite Part B, 73 (2015) 82-88.

25) F. C. Liu, J. Liao, Y. Gao, and K. Nakata: Effect of plasma electrolytic oxidation coating on joining metal to plastic, Science and Technology of Welding and Joining, 20 (2015) 291-296.

26) T. Ogawa: 'Secchaku-handbook, fourth ed';2007, Tokyo, NIKKAN KOGYO SHIMBUN Ltd. (in Japanese)

27) K. Nagata, and Y. Nakamura: 'Silane-coupling-zai no kouka to shiyouhou'; 2012, Tokyo, S\&T Publishing inc. (in Japanese)

28) A. Ogawa, K. Iwamoto, H. Ota, M. Takahashi, A. Hirano, T. Nabatame, and A. Toriumi: Design of high-k interfacial layer formation by cycle-by-cycle deposition and annealing method, ECS Transactions, 19 (2009) 129-143.

29) S. Straus, and L. A. Wall: Pyrolysis of Polyamides, Journal of
Research of National Bureau of Standard, 60 (1958) 39-45.

30) S. Straus, L. A. Wall: Influence of Impurities of the Pyrolysis of Polyamides, Journal of Research of National Bureau of Standard, 63 (1959) 269-273.

31) J. A. S. Tenorio, and D. C. R. Espinosa: High-temperature oxidation of Al-Mg alloys, Oxidation of Metals, 53 (2000) 361-373.

32) F. Cheng, H. Zhao, Y. Wang, B. Xiao, and J. Yao: Evolution of surface oxide film of typical aluminum alloy during mediumtemperature brazing process, Transaction of Tianjin University, 20 (2014) 54-59.

33) JIM: 'Metals data book 3rd ed'; 1995, Tokyo, Maruzen, Co., Ltd. (in Japanese)

34) T. Suga, Y. Murai, T. Kobashi, K. Ueno, M. Shindo, K. Kanno, and K. Nakata: Laser brazing of dissimilar joint of austenitic stainless steel and pure copper, Quarterly Journal of The Japan Welding Society, 32 (2014) 28-46. (in Japanese)

35) W. P. Vellinga, G. Eising, F. M. de Wit, J. M. C. Mol, H. Terryn, J. H. W. de Wit, and J. T. M. D. Hosson: Adhesion at Al-hydroxidepolymer interfaces: Influence of chemistry and evidence for microscopic self-pinning, Materials Science and Engineering A, 527 (2010) 5637-5647.

36) W. C. Wagner, and K. Asgar: Effect of interfacial variables on metal-porcelain bonding, Journal of Biomedical Materials Research, 27 (1993) 531-537.

37) J. M. de Gooijer, M. Scheltus, and C. E. Koning: End group modification of polyamide- 6 in supercritical and subcritical fluids: Part 2: Amine and carboxylic acid end group modification with 1,2epoxybutane, The Journal of Supercritical Fluids, 29 (2004) 153164. 